\title{
Nonlinear modeling growth body weight of Mangalarga Marchador horses
}

\author{
Felipe Amorim Caetano Souza ${ }^{1 *}$ Tales Jesus Fernandes ${ }^{2}$ Raquel Silva de Moura ${ }^{3}$ \\ Sarah Laguna Conceição Meirelles ${ }^{3}$ Rafaela Aparecida Ribeiro ${ }^{4}$ \\ Fabiana Oliveira Cunhas ${ }^{5}$ Joel Augusto Muniz ${ }^{2}$
}

\author{
'Programa de Pós-Graduação em Zootecnia, Universidade Federal de Lavras, Campus Universitário, CP 3037, 37200-000, Lavras, MG, Brasil, \\ E-mail: felipeuflazootecnia@yahoo.com. Corresponding author. \\ ${ }^{2}$ Departamento de Estatística, Universidade Federal de Lavras (UFLA), Lavras, MG, Brasil. \\ ${ }^{3}$ Departamento de Zootecnia, Universidade Federal de Lavras (UFLA), Lavras, MG, Brasil. \\ ${ }^{4}$ Curso de Medicina Veterinária, Universidade Federal de Lavras (UFLA), Lavras, MG, Brasil. \\ ${ }^{5}$ Zootecnista autônoma.
}

\begin{abstract}
The analysis of the growth and development of various species has been done using the growth curves of the specific animal based on non-linear models. The objective of the current study was to evaluate the fit of the Brody, Gompertz, Logistic and von Bertalanffy models to the cross-sectional data of the live weight of the MangalargaMarchador horses to identify the best model and make accurate predictions regarding the growth and maturity in the males and females of this breed. The study involved recording the weight of 214 horses, of which 94 were males and 120 were non-pregnant females, between 6 and 153 months of age. The parameters of the model were estimated by employing the method of least squares, using the iteratively regularized Gauss-Newton method and the R software package. Comparison of the models was done based on the following criteria: coefficient of determination $\left(R^{2}\right)$; Residual Standard Deviation (RSD); corrected Akaike Information Criterion (AICc). The estimated weight of the adult horses by the models ranged between $431 \mathrm{~kg}$ and $439 \mathrm{~kg}$ for males and between $416 \mathrm{~kg}$ and $420 \mathrm{~kg}$ for females. The growth curves were studied using the cross-sectional data collection method. For males the von Bertalanffymodel was found to be the most effective in expressing growth, while in females the Brody model was more suitable. The MangalargaMarchador females achieve adult body weight earlier than the males.
\end{abstract}

Key words: age, body weight, cross-sectional method, statistical models.

Modelagem não linear do crescimento em peso vivo de equinos da raça Mangalarga Marchador

RESUMO: O estudo sobre curvas de crescimento animal com base em modelos não lineares tem sido utilizado para análise do crescimento e desenvolvimento de diversas espécies. Neste trabalho objetivou-se avaliar o ajuste dos modelos Brody, Gompertz, Logístico e vonBertalanffy a dados transversais de peso vivo de equinos Mangalarga Marchador, a fim de selecionar o melhor modelo e predizer sobre o crescimento e a maturidade de machos e fêmeas desta raça. Foram pesados 214 equinos, sendo 94 machos e 120 fêmeas não gestantes, com idade variando entre seis e 153 meses. A estimação dos parâmetros dos modelos foi realizada pelo método de mínimos quadrados, utilizando o processo iterativo de Gauss-Newton, seguindo rotinas do Software R. Os modelos foram comparados pelos critérios: coeficiente de determinação $\left(R^{2}\right)$; desvio padrão residual (DPR); critério de informação de Akaike corrigido (AIC). O peso adulto, estimado pelos modelos, variou entre $431 \mathrm{~kg}$ e $439 \mathrm{~kg}$ para os machos e entre $416 \mathrm{~kg}$ e $420 \mathrm{~kg}$ para fêmeas. O método transversal de obtenção de dados pode ser aplicado no estudo de curvas de crescimento. $O$ modelo de vonBertalanffy foi o mais eficiente para expressar o crescimento nos machos, enquanto que para as fêmeas, o modelo Brody se mostrou mais apropriado. As fêmeas Mangalarga Marchador são mais precoces que os machos para atingir o peso vivo adulto.

Palavras-chave: idade, peso vivo, método transversal, modelos estatísticos.

\section{INTRODUCTION}

It was in the southern state of Minas Gerais that the MangalargaMarchador (MM) breed of horses had originated, and they rank among the most numerous and widely distributed of the Brazilian races found across the country. These animals have marched gait, docile and hardy, being indicated to for leisure, sports and daily work on the rural properties, including herding of cattle (COSTA et al., 2004).
Increasing variations can be observed in the morphological and functional characteristics of the horses in keeping with their age; this implies that as the horses grow, they show alterations in their linear and angular measurements, which directly affect their body rates and therefore their weights (CABRAL et al., 2004). Over time this growth behavior is represented by a sigmoidal shape and is best described by models which interpret the nonlinear relationship between animal characteristics and age (FREITAS, 2005). 
To achieve a good understanding of the dynamics between body weight and other features with respect to age, animal growth curves from non-linear models have been studied as a means of analyzing the development of different species. It facilitates an easy summarization of the information contained in the data of a set of specifically defined parameters, offering biological interpretation of interest from the management perspective (MAZZINI et al., 2005; MENDES et al., 2008; CARNEIRO et al., 2014). The main objectives of growth curve modeling include a description and prediction of the growth and maturity of the animals, as well as the ability to make inferences constructed on the interpretation of the parameters included in the models (LOBO et al., 2006).

While preparing the growth curves, two main types of data collection are used: the cross-sectional and longitudinal methods. The cross-sectional method is the most commonly utilized in human development studies, as it is less expensive, quick and easy to use (SILVA et al., 2010; SPERANDIO et al., 2011). The curves in this method are composed by using the measurements drawn once from a single sample of a population. The longitudinal method involves data which are collected from the same group of individuals, from birth to the adult stage. This method most frequently finds use in monitoring the growth of the animal, however, there is a need for long-term monitoring (ZEFERINO et al., 2003).

Only a few studies are available on monitoring growth curves in horses, in which the samples obtained from repeated measurements in the same animal, from birth to adulthood, are usually considered (SANTOS et al., 2007; MCMANUS et al., 2010; FRALDINHO et al., 2015). This type of experimental procedure poses a difficulty in realizing the research of the species in this area, as it takes up to five years to reach the adult stage, and most farms retain only very few animals until this age. This is because the main source of income for the planners involved with horse production comes from the sale of foals.

Furthermore, when measurements of the same animal are repeatedly done, a dependence of errors occurs, which affects the properties of the estimates. This necessitates adopting autoregressive models which are generally more complex and can result in a worse fit (MAZZINI et al., 2005). Another option that is effective in such a situation is to use the cross-sectional data collection method, employing nonlinear models. To date, no reports of studies are available dealing with modeling the growth curves in Mangalarga Marchador horses.

The aim of this paper was to evaluate the adjustment of the Brody, Gompertz, Logistic and von Bertalanffy models with the data on the live weight of the Mangalarga Marchador horses obtained by the cross-sectional data collection method in order to identify the best model and predict the growth and maturity of the males and females of this breed.

\section{MATERIALS AND METHODS}

In this study, the experimental data were collected in 2012 during an agricultural exhibition at Belo Horizonte - MG, after getting the approval of the Research Ethics Committee, under protocol 039/12. A total of 214 Mangalarga Marchador horses were used (MM), 94 of which were males and 120 were non-pregnant females. The horses ranged from 6 to 153 months in age and were individually weighed in the exhibition park using the conventional mechanical Filizola ${ }^{\circledR}$ weighing scale which had been installed and calibrated.

The cross-sectional collection method was used to develop the growth curves from the measurements recorded from the samples of the MangalargaMarchador horses, to show the sigmoid nature of the data as an expression of the growth of the species.

Four non-linear models, Brody (1), Gompertz (2) Logistic (3) and von Bertalanffy (4) were used to explain the growth curve in terms of the Body weight of the horses of both sexes, based on the following equations:

$$
\begin{aligned}
& y_{i}=a *\left\{1-\exp \left[b-k t_{i}\right]\right\}+\varepsilon_{i} \\
& y_{i}=a * \exp \left\{-\exp \left[b-k t_{i}\right]\right\}+\varepsilon_{i} \\
& y_{i}=a *\left\{1-\exp \left[b-k t_{i}\right]\right\}^{3}+\varepsilon_{i} \\
& y_{i}=\frac{a}{\left\{1-\exp \left[b-k t_{i}\right]\right\}}+\varepsilon_{i}
\end{aligned}
$$

In equations (1), (2), (3) and (4) "” refers to the body weight of the horse in $\mathrm{kg}$; "a" is the asymptotic value or adult weight of the horse; " $b$ " is the inflection point, which implies the age at which the animal experiences rapid growth decelerated for growth until constant weight is attained at its maximum value; " $k$ " shows the growth rate of the horse in terms of weight, or the earliness ratio, because the higher the value of $\mathrm{k}$, the less will be the time needed for the animal to attain the mature body weight and " $t$ " means the age at which the horse was weighed; " $\varepsilon_{i}$ " is the associated experimental error as in the body weight; this is assumed to be a random, independent and normal distribution $\mathrm{N}(0, \sigma 2)$. 
The parameters of the model were estimated using the method of least squares according to DRAPER \&SMITH (1998). The Gauss-Newton numerical algorithm was employed based on the $\mathrm{R}$ statistical software package ( $\mathrm{R}$ Development Core Team, 2015) and the parameters were estimated by the gnls function; the function involved adjusting the nonlinear models using the generalized least squares technique, the nlme package. The Shapiro-Wilk test was used to check the normality of the data.

The comparison and selection of the most appropriate model that best explained the growth curve were done based on the set of quality evaluators mentioned below: i. the residual standard deviation (RSD) was calculated by the expression $\mathrm{RSD}=\sqrt{ }(\mathrm{MSE})$, and MSE the mean square error. The lower in the RSD better the model fit. ii. Coefficient of determination $\left(\mathrm{R}^{2}\right)$ obtained by: $R^{2}=1-\frac{S S E}{S S T}$

where SSE refers to the sum of the squared residuals and SST is the sum total of the squares. The determination coefficient ranges from 0 to 1 , with the best fit seen in the model which has the $\mathrm{R}^{2}$ value closer to 1. iii. the corrected Akaike information criterion (AICc), calculated by the expression

$$
\ln S S E / n+2(q+1)+\frac{2(q+1)(q+2)}{n-(q+2)}
$$

in which $\mathrm{n}$ is the sample size and $\mathrm{q}$ is the number of model parameters. The smaller the AICc value the better is the setting provided by the model.

\section{RESULTS AND DISCUSSION}

Table 1 shows the assumption of normality of the errors according to the Shapiro-Wilk test for all the models (P-value $>0.05)$. The set of quality indicators indicates that all the four models clearly described the development of the weight of these horses with the values of the coefficient of determination above $91 \%$, showing that the von Bertalanffy model has a slightly higher advantage for males, while the Brody model best suits the females, who also achieved lower $R S D$ and $A I C C$ values.

Contrary to the current study, FRALDINHO et al. (2015) noted that the Richards model more effectively explained the standard description of growth of the Lusitanos horses when compared with the Brody, Logistic, Gompertz and von Bertalanffy models. The findings of ONODA et al. (2011) concurred with those of the authors who regarded the Richards model better than the other linear and nonlinear models in the study of the growth of race horses. However SANTOS et al. (2007) concluded that the Weibull model was more suitable to explain the growth curve of weight gain in the Pantaneira breed. In this study an attempt was made to adjust the Weibull and Richards models, but there was no convergence of the parameter estimation algorithms for both males to females, which disqualified them from being used. This, therefore, strengthens the necessity to carefully study the growth curves, as the models have been revealed to describe them only for a particular species or breed and cannot achieve accurate results for the others.

McMANUS et al. (2010) reported results concurring with those obtained in the females MangalargaMarchador (MM) horses, and suggested that the curve obtained by the Brody equation better described the growth of horses of the Hanoverian breed, Brazilian Showjumper,English Thoroughbred and Crossbred (English Thoroughbred x Brazilian Showjumper) of the Brazilian army. The $\mathrm{R}^{2}$ values recorded by these authors were in the range of 0.59 to 0.69 , differing from the $\mathrm{R}^{2}$ values seen in this study $(>0.91)$. As the data on the body weight of the horses were collected by the cross-sectional method, focus on the different characteristics and regions and therefore the dissimilarities in feed management, the quality of fit achieved could have been related to the errors from the independent measurements not repeated in the same animal. Therefore, the cross-sectional method can be utilized to describe the growth curve in horses, including giving parameters consistent with the standard Mangalarga Marchador horses.

From the estimates of mature weight revealed by the models studied, the results are consistent with the racial standard of the MM breed, because these animals are classified as eumetric, i.e. having a live weight of $350-550 \mathrm{~kg}$. The present study recorded weights ranging from $416 \mathrm{~kg}$ to $420 \mathrm{~kg}$ for females and $431 \mathrm{~kg}$ to $439 \mathrm{~kg}$ for males. The difference in the growth patterns clearly showed variations based on sex, according to which the males were heavier than the females. This was confirmed by the estimates of parameter "a" in all the four models (Table 2). This phenomenon is best explained by sexual dimorphism, because the males possess secondary sexual characteristics that influence the growth of some portions of the body, which in turn directly influence the body weight. SANTOS et al., (2007) also observed differences in the body weight between the sexes in the Pantaneiro horses, the males always being heavier, similar to the findings of MCMANUS et al. (2010) in the Brazilian army horses. GARCIA et al. (2011) in their studies revealed the English Thoroughbreddifference in weight between the males 
Table 1 - The p-value of the Shapiro-Wilk test (SW), the coefficient of determination $\left(\mathrm{R}^{2}\right)$, residual standard deviation (RSD) and corrected Akaike information criterion (AICc), in assessing the fit of the growth models of the male and female Mangalarga Marchador horses.

\begin{tabular}{|c|c|c|c|c|c|}
\hline Models & Sex & $\mathrm{SW}^{*}$ & $\mathrm{R}^{2}$ & DPR & $\mathrm{AICc}$ \\
\hline \multirow{2}{*}{ Brody } & Males & 0.8408 & 0.9138 & 23.88 & 399.7957 \\
\hline & Females & 0.8544 & 0.9223 & 20.65 & 511.8354 \\
\hline \multirow{2}{*}{ Gompertz } & Males & 0.8633 & 0.9137 & 23.88 & 399.8071 \\
\hline & Females & 0.8695 & 0.9165 & 21.16 & 515.1416 \\
\hline \multirow{2}{*}{ Logistic } & Males & 0.8325 & 0.9114 & 24.10 & 400.5839 \\
\hline & Females & 0.8297 & 0.9100 & 21.90 & 518.5168 \\
\hline \multirow{2}{*}{ von Bertalanffy } & Males & 0.8741 & 0.9140 & 23.85 & 399.6911 \\
\hline & Females & 0.9054 & 0.9185 & 21.05 & 514.0019 \\
\hline
\end{tabular}

and females right from birth, demonstrating that as the males are usually heavier at birth, it significantly influences their weight as adults.

Females showed earlier weight gain than the males, with a higher estimated value of $\mathrm{k}$ (Table 2). This may be linked to the type of farm management followed in the MM farms during the first year of the life of the animals, a period of immense growth of the body. The females of this breed are generally given good nourishment and the highest quality of health management from the time they are fillies. This is because they are perceived as future mothers and embryo donors and have greater value than the males in this age group, irrespective of whether they will participate in agricultural exhibitions or not. Besides, selection pressure is higher for the males than females, with only a few animals selected for reproduction, and the majority of them are meant for sale; there is no management of these in the first year of life. In their work SANTOS et al. (2007) reported that the pantaneiras females were more precocious, contrary to the findings of MCMANUS et al. (2010) who recorded no difference in the maturation rates of both sexes. In the Lusitanobreed, the males showed higher precocity than did the females, indicating that these differences arose from the sexual dimorphism present in the species (FRALDINHO et al., 2015).

Comparing the $k$ values found in the breed MM (Table 2) against shown by FRALDINHO et al. (2015) in the Lusitano breed $(\mathrm{k}=0.0010)$ the values were observed to be higher in the MM animals. However, this Portuguese breed has continued to be used at the base of the production of the MM horses (SANTIAGO et al., 2014), which may possibly be linked to the smaller sizes of this Brazilian breed. This finding concurred with that of FRALDINHO et al. (2015), in which they noted the slower increase in the live

Table 2 - Estimated parameters and the upper and lower limits of the confidence intervals for all four models describing the growth curve of the female and male Mangalarga Marchador horses.

\begin{tabular}{|c|c|c|c|c|c|c|c|c|c|}
\hline \multirow{2}{*}{ Models } & \\
\hline & $\mathrm{LI}^{*}$ & a & LS & LI & $\mathrm{k}$ & LS & LI & $\mathrm{b}$ & LS \\
\hline \multicolumn{10}{|c|}{ 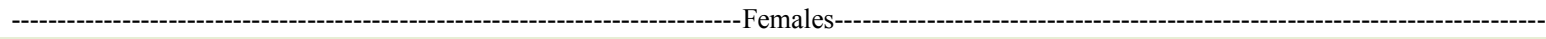 } \\
\hline Brody & 411.81 & 419.70 & 427.98 & 0.065 & 0.078 & 0.094 & -2.200 & 0.084 & 1.816 \\
\hline Gompertz & 410.10 & 417.90 & 426.05 & 0.080 & 0.098 & 0.119 & 3.403 & 5.155 & 6.494 \\
\hline Logistic & 408.72 & 416.57 & 424.67 & 0.096 & 0.119 & 0.147 & 7.318 & 8.789 & 10.000 \\
\hline Von Bertalanffy & 410.63 & 418.50 & 426.62 & 0.075 & 0.091 & 0.110 & 5.051 & 8.376 & 12.662 \\
\hline \multicolumn{10}{|c|}{ 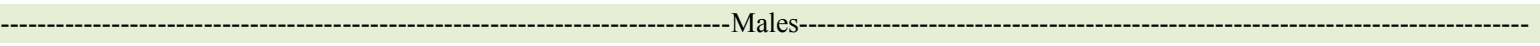 } \\
\hline Brody & 424.83 & 439.16 & 455.99 & 0.035 & 0.046 & 0.059 & -10.182 & -5.278 & -1.7696 \\
\hline Gompertz & 421.53 & 434.60 & 449.57 & 0.046 & 0.059 & 0.075 & 0.1033 & 3.333 & 5.7338 \\
\hline Logistic & 419.02 & 431.40 & 445.32 & 0.057 & 0.073 & 0.093 & 6.6514 & 9.190 & 11.2911 \\
\hline Von Bertalanffy & 422.53 & 436.00 & 451.40 & 0.042 & 0.051 & 0.069 & 12.610 & 19.090 & 27.9170 \\
\hline
\end{tabular}

* Legend: $\mathrm{a}=$ is the asymptotic value or adult weight of the animal; $\mathrm{b}=$ is a location parameter associated with the inflection point of the model; $\mathrm{k}=$ is the maturity index and precocity of the model; $\mathrm{LI}=$ lower limit of the confidence interval; $\mathrm{LS}=$ upper limit of the confidence interval. 
weight of the Lusitanos animals when compared with the others in sports breed.

A greater and more homogeneous growth was evident in the MM horses from 6 to 24 months of age (Figure 1). GARCIA et al. (2011) noted a higher growth rate in the English Thoroughbred foals from birth to thirty days, after which the weight gain gradually declined. SANTOS et al. (2007) too reported less variations and higher growth in the early years of the Pantaneiro horses. These observations may have some bearing on the allometric and compensatory growth of bone, muscle and adipose tissues, a little known feature in the equine species until even today. This could possibly result in the different characteristic growth patterns, like body weight, which are of great zootechnical concern.

After the age of 24 months, a greater variability in the body weight was reported as age increased in the MM animals. This variation could be linked to genetics as well as the animal handling methods that these animals were put through during their work life, for example, disablement or nutritional excesses, health issues, stressful conditions in the environment and training, to mention a few (SANTOS et al., 2007). Another factor that can throw light on this fact is the heterogeneity present in the MangalargaMarchador herd, as the race is still in training and whose selection commenced only about 200 years ago (SANTIAGO et al., 2014).

After 60 months of age, a stabilization of the growth curve was evident in both sexes
(Figure 1), implying that the growth of the MM horses in body weight is almost similar at this age. This growth pattern showed some differences from the development seen in the horses belonging to the four genetic study groups as reported by MCMANUS et al. (2010) which achieved adult weight within three years. The MM breeds has a functional type of saddle biotype forworking, differently of breeds used by MCMANUS et al. (2010), which are considered saddle types for the sport breed.

The increased knowledge regarding the growth of the MangalargaMarchador horses from the curves thus studied can enable a better emphasis to be placed on the nutrition and health management practices in horse farms, and predict in advance the ways of distributing animal growth to facilitate proper intervention in the management, particularly during the first years of life (SANTOS et al., 2007). This will negate the administration of growth hormones and improve improper diets to offset any type of developmental losses, which can be detrimental to the health of the horses and thus raise the cost of the production of the characteristics that go into the formation of this race.

\section{CONCLUSION}

The cross-sectional data collection method can be applied to study the growth curves of the body weight using nonlinear models in the MangalargaMarchador horses. The von Bertalanffy model was
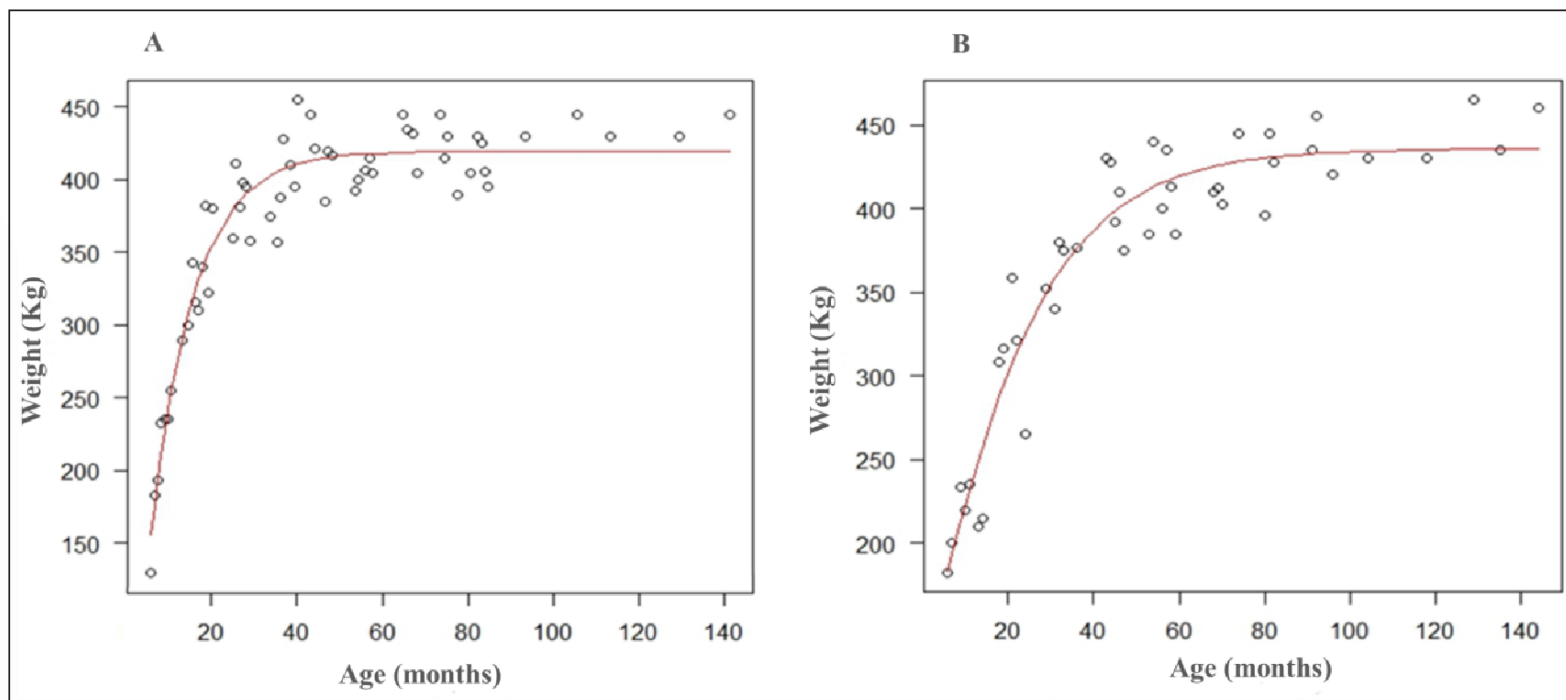

Figure 1 - Representation of the growth curve obtained by nonlinear Brody model for females (A) and the von Bertalanffy model for males (B) of the Mangalarga Marchador horses. 
more suitable to use for the males while the Brody model was better for the females.

The increase in weight gain is observed to be faster and more homogeneous from age 6 to 24 months in the MangalargaMarchador horses, stabilizing at 60 months in both sexes; however, females have a higher precocity than males to attain adult weight.

\section{ACKNOWLEDGMENT}

The Center for Studies in Equideocultura Universidade Federal de Lavras (UFLA) (NEQUI), Fundação de Amparo à Pesquisa do Estado de Minas Gerais (FAPEMIG), Conselho Nacional de Desenvolvimento Científico e Tecnológico $(\mathrm{CNPq})$ and veterinarian José Carlos Magalhães for his assistance in the assessment of the horses and collection of data.

\section{REFERENCES}

CABRAL, G.C. et al. Morphometric evaluation of Mangalarga Marchador horse: conformation index and body. Revista Brasileira de Zootecnia, v.33, n.6, p.1798-1805, 2004. Available from: <http://dx.doi.org/10.1590/S1516-35982004000700018>. Accessed: Oct. 05, 2015.doi: 10.1590/S1516-35982004000700018.

CARNEIRO, A.P.S. et al. Identity of nonlinear models to compare growth curves of the cattle breed Tabapuã. Pesquisa Agropecuária Brasileira, v.49, n.1, p.57-62, 2014. Available from: <http:// dx.doi.org/10.1590/S0100-204X2014000100008>. Accessed: Jul. 07, 2015.doi: 10.1590/S0100-204X2014000100008.

COSTA, M.D. et al. Demographic characterization of MangalargaMarchador breed. Arquivo Brasileiro Medicina Veterinária e Zootecnia, v.56, p.687-690, 2004. Available from: <http://dx.doi. org/10.1590/S0102-09352004000500020>. Accessed: Jan. 20, 2015.doi:10.1590/S0102-09352004000500020.

DRAPER, N.R.; SMITH, H. Applied regression analysis.3.ed. New York: J. Wiley, 1998. 706p.

FRALDINHO, M.J. et al.Growth and development of the Lusitano horse managed on grazing systems. Livestock Science, v.12, p.1871-1413, 2015. Available from: <http://dx.doi.org/10.1016/j. livsci.2015.06.006>. Accessed: Aug. 02, 2015. doi:10.1016/j. livsci.2015.06.006.

FREITAS A.R. Growth Curves in Animal Production.Revista Brasileira de Zootecnia, v.34, n.3, p.786-795, 2005. Available from: $<$ http://www. scielo.br/pdf/rbz/v34n3/a10v34n3>. Accessed: Nov. 10, 2014.

GARCIA, F.P.S. et al.Growth and development rates in thoroughbred foals in Bagé-Brazil. Revista Portuguesa de Ciências Veterinárias, v.106, p.43-46, 2011. Available from: $<$ http://www.fmv.ulisboa.pt/spcv/PDF/pdf12_2011.old/43-46. pdf>. Accessed: Mar. 25,2015.

LOBO, R.N.B. et al. Genetic parameters for traits estimated from the growth curve of Santa Inês hair sheep. Revista Brasileira de Zootecnia, v.35, n.3, p.1012-1019, 2006.Available from: $<$ http://www.scielo.br/pdf/\%0D/rbz/v35n3s0/30712.pdf $>$. Accessed: Apr. 28, 2015.

MAZZINI A.R.A. et al.Growth curve for hereford males: heterocedasticity and autoregressives residuals. Ciência Rural, v.35, n.2, p.422-427, 2005.Available from: <http:// www.scielo.br/pdf/\%0D/cr/v35n2/a28v35n2.pdf>. Accessed: Jun. 08, 2015.

MCMANUS C.M. et al. Nonlinear growth curves for weight and height in four genetic groups of horses. Ciência Animal Brasileira, v.11, n.1, p.80-89, 2010.Available from: $<$ https://doi.org/10.5216/ cab.v11i1.5400>. Accessed: Sep. 17, 2015.doi:10.5216/cab. v11i1.5400.

MENDES, P.N.et al.Difasics logistic model in the study of the growth of Hereford breed females. Ciência Rural, v.38, n.7, p.1984-1990, 2008.Available from: <http://www.scielo.br/pdf/cr/ v38n7/a29v38n7.pdf>. Accessed: Sep. 17, 2015.

ONODA, T. et al. Empirical growth curve estimation using sigmoid sub-functions that adjust seasonal compensatory growth for male body weight of thoroughbred horses. Journal Equine Science, v.22, n.2, p.37-42, 2011. Available from: <http//doi. org/10.1294/jes.22.37>. Accessed: Jan. 15, 2016. doi:10.1294/ jes.22.37.

$\mathrm{R}$ DEVELOPMENT CORE TEAM. R: a language and environment for statisticalcomputing. Vienna: $R$ Foundation for Statistical Computing, 2012. Available from: <http://www.rproject.org>.Accessed: June 12,2012.

SANTIAGO, J.M.et al. Morphometric measurements of current herd MangalargaMarchador females and champions of breed. Revista Brasileira Saúde e Produção animal, v.15, n.1, p.141148, 2014. Available from: <http://revistas.ufba.br/index.php/ rbspa/article/view/2792/1495>. Accessed: Feb. 09, 2015.

SANTOS, S.A. et al. Monitoring body development of pantaneiros horses by growth curves. Archivos de Zootecnia, v.56, Supl.1, p.648, 2007. Available from: <http://www.uco.es/organiza/ servicios/publica/az/php/img/web/01_08_53_47MonitoramentoSa ntos.pdf>. Accessed: Dec. 09, 2015.

SILVA, D.A.S. et al.Comparison between the growth of Brazilian children and adolescents and the reference growth charts: data from a Brazilian project. Jornal de Pediatria, v. 86, n.2, p.115120,2010. Available from: <http://dx.doi.org/10.1590/S002175572010000200006>. Accessed: May. 12, 2016.doi:10.1590/ S0021-75572010000200006.

SPERANDIO, N. et al.Comparison of the nutritional status during childhood with different growth curves. Revista de Nutrição, v.24, n.4, p.565-574, 2011.Available from: <http://dx.doi. org/10.1590/S1415-52732011000400005>. Accessed: Jul. 14, 2016. doi:10.1590/S1415-52732011000400005.

ZEFERINO, A.M.B. et al. Monitoringgrowth. Jornal de Pediatria, v.79, n.1, p.23-32, 2003. Available from: <http:// www.scielo.br/pdf/\%0D/jped/v79s1/v79s1a04.pdf $>$. Accessed: Aug. 20, 2016. 